\title{
Ethnoveterinary medicinal plants application for the treatment of tick-borne diseases in cattle around the Eastern Cape Province of South Africa
}

\begin{tabular}{|c|c|}
\hline \multicolumn{2}{|c|}{$\begin{array}{l}\text { Authors: } \\
\text { Siza Mthi }{ }^{1} \text { (D) } \\
\text { Jean Rust }{ }^{1} \text { (D) } \\
\text { Mandla Yawa }{ }^{2} \text { (D) } \\
\text { Louis Tyasi }^{3} \text { (D) }\end{array}$} \\
\hline \multicolumn{2}{|c|}{$\begin{array}{l}\text { Affiliations: } \\
{ }^{1} \text { Department of Agriculture, } \\
\text { Dohne Agricultural } \\
\text { Development Institute, } \\
\text { Stutterheim, South Africa }\end{array}$} \\
\hline \multicolumn{2}{|c|}{$\begin{array}{l}{ }^{2} \text { Department of Livestock and } \\
\text { Pasture Science, Fort Hare } \\
\text { University, Alice, South Africa }\end{array}$} \\
\hline \multicolumn{2}{|c|}{$\begin{array}{l}{ }^{3} \text { Department of Agriculture } \\
\text { Economics and Animal } \\
\text { Production, University of } \\
\text { Limpopo, Polokwane, } \\
\text { South Africa }\end{array}$} \\
\hline \multicolumn{2}{|c|}{$\begin{array}{l}\text { Corresponding author: } \\
\text { Siza Mthi, } \\
\text { sizamthie@gmail.com }\end{array}$} \\
\hline \multicolumn{2}{|c|}{$\begin{array}{l}\text { Dates: } \\
\text { Received: } 19 \text { June } 2020 \\
\text { Accepted: } 15 \text { Aug. } 2020 \\
\text { Published: } 29 \text { Oct. } 2020\end{array}$} \\
\hline \multicolumn{2}{|c|}{$\begin{array}{l}\text { How to cite this article: } \\
\text { Mthi, S., Rust, J., Yawa, M. } \\
\text { \& Tyasi, L., 2020, } \\
\text { 'Ethnoveterinary medicinal } \\
\text { plants application for the } \\
\text { treatment of tick-borne } \\
\text { diseases in cattle around the } \\
\text { Eastern Cape Province of } \\
\text { South Africa', Journal of } \\
\text { Medicinal Plants for Economic } \\
\text { Development 4(1), a100. } \\
\text { https://doi.org/10.4102/ } \\
\text { jomped.v4i1.100 }\end{array}$} \\
\hline \multicolumn{2}{|c|}{$\begin{array}{l}\text { Copyright: } \\
\text { (C) 2020. The Authors. } \\
\text { Licensee: AOSIS. This work } \\
\text { is licensed under the } \\
\text { Creative Commons } \\
\text { Attribution License. }\end{array}$} \\
\hline \multicolumn{2}{|l|}{ Read online: } \\
\hline 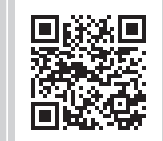 & $\begin{array}{l}\text { Scan this QR } \\
\text { code with your } \\
\text { smart phone or } \\
\text { mobile device } \\
\text { to read online. }\end{array}$ \\
\hline
\end{tabular}

Background: South Africa is recognised as one of the most biodiverse countries in terms of fauna and flora in the sub-Saharan region. More than $40 \%$ of farmers in remote rural areas of the Eastern Cape Province use medicinal plants for the treatment of different livestock ailments.

Aim: The aim of the study was to identify and document plant species used for the treatment of tick-borne diseases in the Amathole and O.R. Tambo district municipalities of the Eastern Cape, South Africa.

Methods: Semi-structured questionnaire was employed to obtain detailed information of ethnoveterinary medicinal plants used including parts, mode of preparation and mode of administration from 48 respondents between November 2013 and February 2014. The collected plant species were identified scientifically at the Stutterheim Dohne Herbarium, where voucher numbers were obtained and herbarium specimens were deposited. Data collected were subjected to descriptive statistical analysis.

Results: A total of nine medicinal plant species belonging to eight families and represented by nine genera were identified. The most dominant inhabitants were trees $(55.6 \%)$, followed by herbs (33.3\%) and shrubs (11.1\%). The most frequently used plant families for tick-borne diseases were Xanthorrhoeaceae, Ebenaceae, Proteaceae, Malvaceae, Asteraceae, Vitaceae, Loganiaceae and Iridaceae, and from these plant families, leaves (44.4\%) were the most commonly used plant parts.

Conclusion: The data display that people in rural areas have preserved some knowledge of ethnoveterinary practices for the treatment of tick-borne diseases. However, further studies on plants used for the treatment of tick-borne diseases can be advanced towards validation and standardisation by evaluating parameters such as efficacy, safety and toxicity, quality (phytochemicals) and dosage standards.

Keywords: ethnoveterinary; medicinal plants; treatment; tick-borne diseases; cattle.

\section{Introduction}

South Africa holds huge and diverse livestock species, estimated at about 12608 million heads of cattle, 22213 million sheep and 5276 million goats of which more than $40 \%$ is owned by smallholder farmers (Department of Forestry and Fisheries 2019). Cattle production like other livestock species is a fundamental resource to the well-being of people who live in the rural areas of South Africa (Bettencourt et al. 2015; Nyahangare et al. 2015) and are reared for the provision of milk, meat, fibre, manure and draught power (Chimonyo et al. 1999; Hadi et al. 2002; Moyo \& Swanepoel 2010).

Although the communal sector is rich in its livestock population, productivity is low as compared to the commercial (Bembridge 1989). Among other factors, the high prevalence of diseases and poor health management under small-scale farming system across all livestock species are the major constraints responsible for the low productivity. One of the major concerns affecting livestock in the tropics and subtropics are ixodid ticks such as Rhipicephalus species, which transmit pathogens that cause tick-borne diseases such as heartwater. Disease caused by ticks is a global problem and considered a major obstacle in the health and product performance of animals (Ocaido, Muwazi \& Asibo 2008). Global losses to livestock because of tick and tick-borne diseases are estimated at \$22-355 billion per annum (Lew-Tabor \& Rodriguez Valle 2016), especially Rhipicephalus species (Nana 2010). 
Diseases affect not only the production but also the import and export of animal products. The use of synthetic acaricides through plunge dipping, spray race and hand spraying are still the main approaches used to control ticks and tick-borne diseases (George, Pound \& Davey 2004). It has been shown that excessive use of synthetic acaricides has resulted in the development of tick resistance to most of these pesticide products (Martins et al. 1995; Ntondini et al. 2008; Rajput et al. 2006). More so, the situation has called for concern by environmentalist inview of the widespread residual effect of chemical acaricides on the consumers and the environment. Thus, with the availability of acaricides in rural areas (Scialabba 2000) and the high cost of synthetic acaricides (Graf et al. 2004), one will be quick to attribute these as likely reasons that prompt farmers to seek alternative ways of control and strategies from natural products to cope their livestock diseases (Breyer-Brandwijk \& Watt 1962).

This study sought to collect, identify and document the indigenous knowledge and plants used in ethnoveterinary practices by resource-limited farmers found in certain parts of the Eastern Cape Province of South Africa. The research is thus aimed at providing some baseline information and the need for documentation to serve as a reference database (information) for drug discovery research and development. It may as well contribute to the conservation and preservation of biological resources.

\section{Materials and methods Study area and research design}

The study which took place between November 2013 and February 2014 was conducted in three villages found in two districts (Figure 1): two villages, namely Upper Gqumeya village under Amathole district municipality and Amahlathi local municipality which is found $10 \mathrm{~km}$ South of Keiskammahoek town, 32043'08.87'S longitude and 27007'42.14"E latitude. The vegetation is a mixture of thicket, forests, savanna and grassland. Ciko village under Amathole district municipality and Mbashe local municipality is found $7 \mathrm{~km}$ East of Willowvale town, 32016'11.18"S longitude and $28032^{\prime} 03.22$ "E latitude with a vegetation of thickets of the Eastern Valley Bushveld. The third village called Goso from O.R. Tambo district and Ngquza Hill local municipality is found $15 \mathrm{~km}$ South of Lusikisiki town, 31022'49.38"S longitude and 29035'48.57"E latitude with a vegetation of Indian Coastal Belt. The three villages were selected with an intent based on the number of livestock and knowledgeable people with medicinal plants. Acquisition of information relied on the facts that majority of the inhabitants from the two districts of the study areas depend grossly on natural and indigenous knowledge sources for their livestock healthcare needs. Consequently, the two districts have retained some rich biodiversified flora. More so, agriculture is the main stay and economic activity here, mainly characterised by livestock and crop farming in the

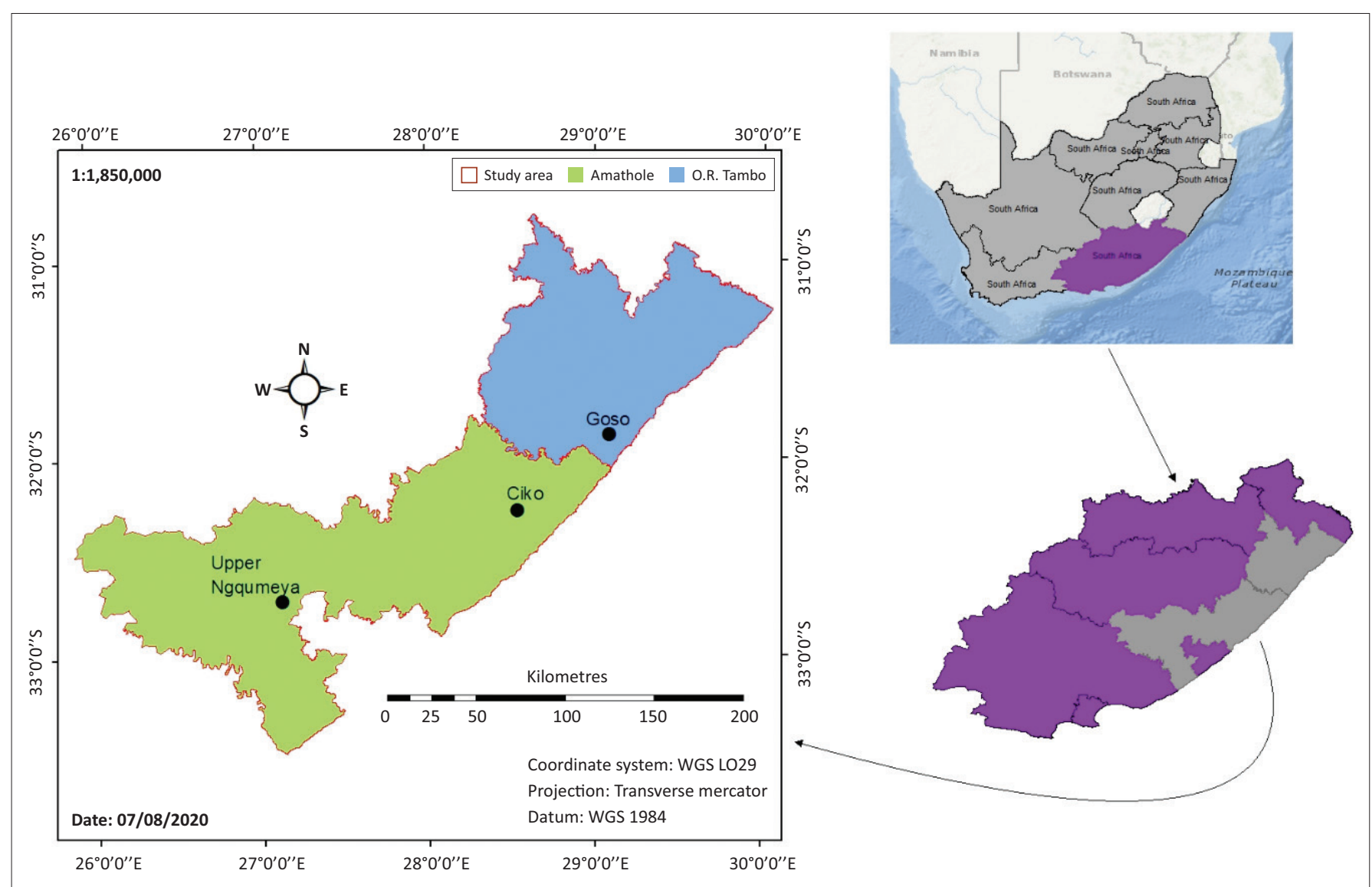

FIGURE 1: South African map showing the study area. 
municipalities of the two districts. Thus, the suitability of the study area became more pertinent, as it was apparent that livestock in a communal farming system are prone to diseases because of high interactions between animals from different households as some may not be vaccinated against contagious diseases. Most rural areas in the Eastern Cape province are far from healthcare facilities, and farmers tend to use medicinal plants as an alternative for the treatment of livestock diseases.

\section{Sampling procedure}

The purposive sampling method as described by Tongco (2007) was used to select the three villages and participants. A total of 48 participants from 48 households were selected with the assistance of extension officers, community elders and local authorities based on their traditional knowledge of medicinal plants and willingness to participate and the livestock they own. Each participant was separately interviewed orally with the aid of a questionnaire in their vernacular language (IsiXhosa) and later translated to English by the research team from Dohne Agricultural Development Institute. Information regarding the local name of ethnoveterinary medicinal plants, mode of preparation and administration, parasitic disease treated, route of administration, source of the medicinal plants and plant parts used was collected.

\section{Preservation of collected plants}

The procured medicinal plant species were pressed, dried and mounted on cardboard sheets as standard herbarium specimens prepared, which were later properly identified using the Flora of South Africa as illustrated in the published book 'Trees of South Africa' (Palmer \& Pitman 1972; Schmidt et al. 2002). The correctly identified specimens (with voucher number) were deposited in the herbarium, Dohne Agricultural Development Institute, Stutterheim in the Eastern Cape Province.

\section{Data analysis}

Data on livestock diseases treated, used plant local names, preparation methods and administration route were recorded. Collected data were analysed using Statistical Package for Social Science (SPSS, 2011, version 20, United States) in order to generate descriptive statistics to achieve the objective of the study, and scientific family and species names of the plants were achieved after botanical identification.

\section{Ethical consideration}

In order to protect the rights and welfare of the interviewees, guidelines based on the protection of indigenous knowledge bill (2013) were followed (registration number: D5633/37/1/1).

\section{Result and discussion Medicinal plants and its application}

The results of the study are presented in Table 1 . The plants are arranged in alphabetical order for each specie identified and documented. Details on botanical name, family, local name, parts used, mode of preparation and administration, habit and therapeutic indication were presented as well. These revealed that informants have knowledge of ethnoveterinary medicinal plants for the healthcare of livestock. A total of nine ethnoveterinary medicinal plant species belonging to eight families were used with various plant parts as extracts or in combination with other substances as a concocted mixture and their combinations for the treatment of three tick-borne diseases in the study areas. Ethnoveterinary medicinal plant used serving as remedy against tick-borne diseases largely reveals that Xanthorrhoeaceae constituted two species, while seven families namely Ebenaceae, Proteaceae, Malvaceae, Asteraceae, Vitaceae, Loganiaceae and Iridaceae contributed one specie each. These findings were thus in agreement with those of Sreekeesoon and Mahommodally (2014) who earlier noticed the dominant use of Xanthorrhoeaceae by Sreekeesoon as used in the treatment of pain in Mauritius. Suffices to say that the various use of medicinal plants in different regions is an indication of their safety and efficacy. The study further showed that the informants in the three villages of Eastern Cape rely on traditional knowledge and practices supported by the availability of a well-endowed regional vegetative biodiversity. Hence, one could attribute firmly the reason for their resorting to nature as primary source of medicine for the cure and prevention of livestock health problems and diseases such as anaplasmosis, babesiosis and heartwater. Some of our findings of ethnoveterinary medicinal plants use by these local (as therapeutically indicated for the treatment of tick-borne diseases by the informants) corroborate with some good

TABLE 1: Ethnoveterinary surveyed medicinal plants of Amathole and O.R. Tambo districts of South Africa.

\begin{tabular}{|c|c|c|c|c|c|c|}
\hline Plant specie and family & $\begin{array}{l}\text { Local or vernacular } \\
\text { (IsiXhosa) name }\end{array}$ & No of citation & Diseases treated & Plant part used & Mode of preparation & Dosage-regiment \\
\hline E. undulata Ebenaceae & Umgwali & 2 & Heartwater & L & $\mathrm{D}$ & 0 \\
\hline P. caffra Proteaceae & Isiqwani & 3 & Heartwater & SE & $\mathrm{D}$ & 0 \\
\hline G. occidentalis Malvaceae & Umnqabaza & 4 & Heartwater & L & D & 0 \\
\hline A. maculata Xanthorrhoeaceae & Unomaweni & 6 & Heartwater & $\mathrm{L}$ & $\mathrm{D}$ & 0 \\
\hline A. ferox Xanthorrhoeaceae & Ikhala & 4 & Babesiosis & L & D & 0 \\
\hline V. mespilifolia Asteraceae & Hlungulwana & 2 & Babesiosis & ST & 1 & 0 \\
\hline R. tomentosa Vitaceae & Chithibunga & 3 & Babesiosis & $B L$ & D & 0 \\
\hline S. henningsii Loganiaceae & Umnonono & 3 & Babesiosis & B & $\mathrm{D}$ & 0 \\
\hline Dietes Iridaceae & Mbona kaxam & 2 & Anaplasmosis & $\mathrm{R}$ & 1 & $\mathrm{O}$ \\
\hline
\end{tabular}

B, bark; BL, bulb; L, leaves; O, oral; R, root; SE, seed; ST, stem. 
number of plants earlier reported to treat different kind of diseases in animals and humans by various organisations in different parts of the world (Sreekeesoon \& Mahommodally 2014). Similarly, Kioko et al. (2015) reported diseases or conditions like anaplasmosis, heartwater and babesiosis.

\section{Identification of disease and associated symptoms}

Various symptoms were stated for the three tick-borne diseases. According to the farmers, lack of appetite, isolation from the herd and stay under shelter were symptoms related to heartwater. Loss in weight and smell, and diarrhoea were the symptoms related to babesiosis. Changes in eye colour from red to yellow was perceived as the sign of anaplasmosis.

\section{Heartwater}

Crushed leaves, seed and roots of Euclea undulata, Protea, Grewia occidentalis and Aloe maculata were used and administered orally to treat heartwater in the study areas. Roots, barks and leaves (whole plant parts) of $E$ undulata were used in various regions of South Africa to treat toothache, body pains and diabetes in humans (Deutschländer et al. 2009a, 2010, 2012; Dzoyem \& Eloff 2015; Motlhanka \& Nthoiwa 2013); whereas in Swaziland, the species were used for heartwater in livestock (Long 2017). Seeds of Protea in the study were used to treat heartwater, while Protea roots were used to cure diarrhoea and dysentery in calves (McGaw \& Eloff 2008). In this study, leaves of G. occidentalis were used to treat heartwater. Soyelu and Masika (2009) reported that leaves and twigs of G. occidentalis lotion can be used to treat wounds in the Amathole Basin of the Eastern Cape. Roots, entire plant and bark were used for childbirth, sterility and wounds, respectively (Bhat 2013). According to the farmers, A. maculata is used for treating heartwater disease in cattle. However, other studies have reported the use A. maculata to treat skin burns in humans (Menendez-Baceta et al. 2013; Maroyi 2017).

\section{Babesiosis}

In this study, leaves, stem, bark and bulb of A. ferox, Vernonia mespilifolia, Rhoicissus tomentosa and Strychnos henningsii were used to treat babesiosis in livestock. According to Tyasi and Gxasheka (2015) in their study, the leaf pulp of Aloe species was administered orally to cure cough, wounds and chest pains. Rhoicissus tomentosa is used by traditional healers to ensure safe delivery during pregnancy (Hutchings et al. 1996b). Seed of $V$. cinerea which belongs to the same family with $V$. mespilifolia were used to cure fever and treat food poisoning (Galav et al. 2010).

\section{Anaplasmosis}

Leaves of dietes and commercial vinegar were mixed to cure anaplasmosis in these study areas. Dreyer, Fourie and Kok (1999) reported that commercial vinegar mixed with sugar can treat anaplasmosis in animals.

\section{Surveyed plant habitat}

The study revealed that all informants (100\%) in the study area collect medicinal plants from the wild. This is in line with the findings of Kamatenesi-Mugisha and OryemOriga (2005) in Uganda; Mwale et al. (2005) in Zimbabwe; and Yineger and Yewhalaw (2007) and Giday, Asfaw and Woldu (2009) in Ethiopia, who found that traditional healers usually collect medicinal plants from the wild.

Analysis of the growth forms of ethnoveterinary medicinal plants in the study areas revealed trees as constituting the largest category with five species, whereas herbs and shrubs account for only three species and one species, respectively (Figure 2). Contrary to our findings, a study conducted by Endashaw (2007) and Reta (2013) showed that herbs constituted the largest category, followed by shrubs and trees in the southern part of Ethiopia. In Ethiopia, the dominance of shrubs was also reported by earlier ethnobotanical inventories (Bekalo, Demissew \& Asfaw 2009; Hunde, Asfaw \& Kelbessa 2006; Lulekal et al. 2008; Mesfin, Demissew \& Tekelaymanot 2009). Similar to our finding, the dominance of trees was reported by Yibrah (2015) in Woreda, Southern Ethiopia. However, in some few cases, the black vinegar was used.

\section{Plant part(s) used and mode of remedy preparation}

The study recorded that several parts of individual plant species were used to prepare medicine to treat various livestock diseases in the three study areas (Table 1). All the plant species were locally available. Different species of Aloe were used to treat two parasitic diseases. In regard to the plant parts collected and used to treat parasitic diseases, the study discovered that the most frequently utilised medicinal plant part was leaves (44.4\%). Bark, root, stem, seed and bulb contribute $11.1 \%$, respectively. This agrees with the findings of Asiimwe et al. (2014), Bradacs, Heilmann and Weckerle (2011), Gebrezgabiher et al. (2013), Leto et al. (2013), Luseba and Tshisikhawe (2013) and

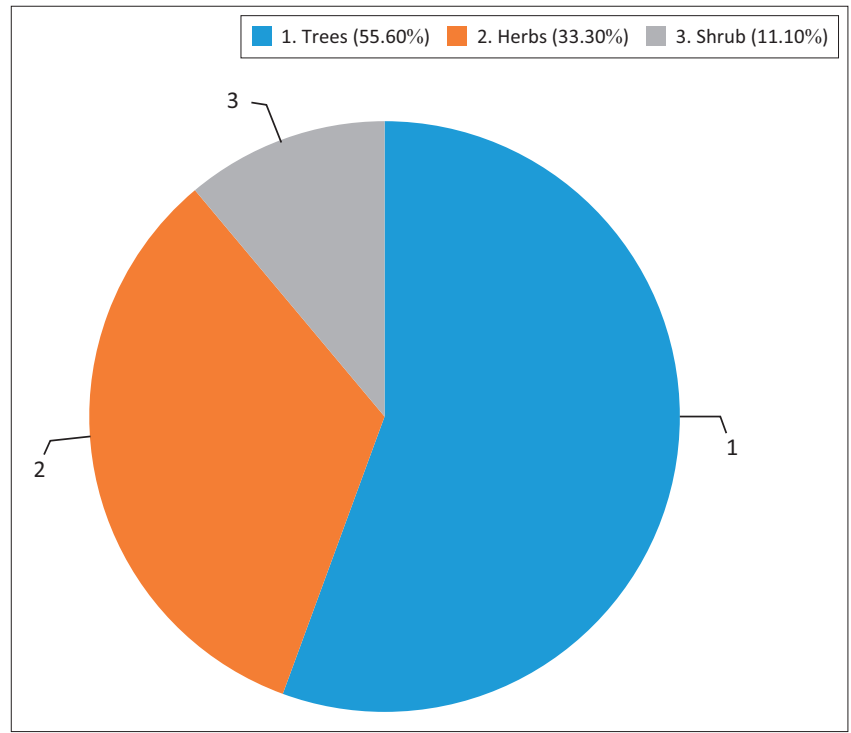

FIGURE 2: Growth habit of medicinal plants in the study sites. 
Mesfin (2007). The reason for the frequent use of leaves is that they are the major site for photosynthesis activity and contain very high concentrations of secondary metabolites (Balick \& Cox 1996; Boadu \& Asase 2017; Ghorbani 2005) which contributes towards their medicinal values. Moreover, easy collection and minimum threat to destroy (old leaves) a plant as compared to the harvesting of roots and barks might be one of the other reasons to use leaves. Additionally, other benefits of using different parts of the plants might be valuable in terms of extracting other bioactive compounds as different parts of the plants differ in the composition of secondary metabolites (Busia 2016). Use of roots, bulb, seeds, stem and barks as the second most preferred plant parts should be condemned as it may lead to the extinction of the plant (Leto et al. 2013).

The majority of remedies in the study areas were processed as decoctions (77.8\%) followed by infusion (22.2\%). The use of one plant against one disease and the mixing of two or more different plants against a single disease were also commonly observed. Similar results were reported by Kakudidi, Bukenya-Ziraba and Kasenene (2000) in Kibale National Park in western Uganda, and Yirga (2012) in Ethiopia.

\section{Mode of knowledge acquisition}

It was observed that inheritance of traditional knowledge of medicinal plants was the major source of knowledge acquisition (Figure 3) amongst the IsiXhosa speaking people of the study sites. Vertical knowledge transmission from grandparents and parents was mentioned by $81 \%$ (39 respondents). On the other hand, horizontal transmission from uncle/aunt and neighbours was reported by $19 \%$ of the respondents (9). These corresponds with studies carried out in other parts of South Africa, Ethiopia, Nigeria and India (Tamiru et al. 2013), as a major concern for knowledge transfer from older to younger generations.

\section{Route of remedy administration and dosage}

Oral administration was the only $(100 \%)$ route of remedy administration. Similar findings were reported by other

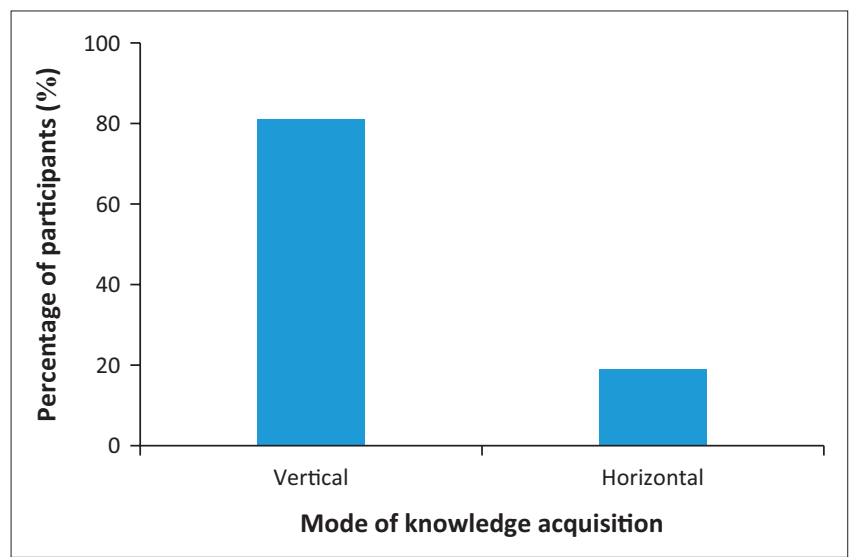

FIGURE 3: Mode of knowledge acquisition. researchers (Bhattarai et al. 2010; Kamatenesi, Acipa \& Oryem-Origa 2011; Mthi et al. 2018). The choice of oral administration over possible alternatives may be related to the use of some solvents (water, vinegar) that are commonly believed to serve as a good vehicle to transport the active principles. Dosage was determined based on the age and frequency of dosage depending on the severity of the condition being treated.

\section{Conclusion}

Nine plant species were identified and used in the treatment of three tick-borne livestock diseases (heartwater, babesiosis and anaplasmosis) in selected rural communities of the Eastern Cape Province. Plants species used (E. undulata, P. caffra, G. occidentalis, A. ferox, A. maculata, V. mespilifolia, R. tomentosa, S. henningsii and Dietes) have been reported by various researchers to have pharmacological importance. However, these surveyed and documented plants as well as their therapeutic indications against the aforementioned veterinary diseases would require validation using standardised procedures for the evaluation of their efficacy, safety (toxicity), quality (phytochemicals) and dosage regiments in order to develop a secured drug.

\section{Acknowledgements}

The authors would like to acknowledge the farmers who willingly participated in this study and the Eastern Cape Department of Rural Development and Agrarian Reform for funding this project.

\section{Competing interests}

The authors declare that they have no financial or personal relationships that may have inappropriately influenced them in writing this article.

\section{Authors' contributions}

S.M. identified the research area and title, collected field data and drafted the manuscript. J.M.R. participated in refining the title and the formation of the research problem. M.Y. and T.T.L. provided useful scientific and technical inputs on the drafting of the manuscript and data analysis. All authors read and approved the final manuscript.

\section{Funding information}

The authors would like to acknowledge the Eastern Cape Department of Rural Development and Agrarian Reform for funding this project. Ethical Clearance was issued by Dohne ADI Research Ethical Committee, certificate number $01 / 2012$.

\section{Data availability statement}

Data sharing is not applicable to this article as no new data were created or analysed in this study. 


\section{Disclaimer}

The views and opinions expressed in this article are those of the authors and do not necessarily reflect the official policy or position of any affiliated agency of the authors.

\section{References}

Asiimwe, S., Namutebi, A., Borg-Karlsoon, A., Mugisha, M.K. \& Oryem-Oringa, H. 2014, 'Documentation and consensus of indigenous knowledge on medicinal plants used by local communities of western Uganda', Journal of Natural Production Plant Resources 4(1), 34-42.

Balick, M.J. \& Cox, P.A., 1996, 'Plants, People and Culture: Science of Ethnobotany', Journal of Natural Products 60(4), 428-429.

Bhat, R.B., 2013, 'Medicinal plants and traditional practices of Xhosa people in the Transkei region of Eastern Cape, South Africa', Indian Journal of Traditional Knowledge 13(2), 292-298.

Bhattarai, S., Chaudhary, R.P., Quave, C.L. \& Taylor, R.S.L., 2010, 'The use of medicinal plants in the trans - Himalayan arid zone of Mustang district, Nepal', Journal of Ethnobiology and Ethnomedicine 6(1), 1-14. https://doi.org/10.1186/1746-42696-14

Bekalo, H.T., Demissew, S. \& Asfaw, Z., 2009, 'An ethnobotanical study of medicinal plants used by local people in the lowlands of Konta Special Wereda, Southern Nations, nationalities and peoples regional state, Ethiopia', Journal of Ethnobiology and Ethnomedicene 5(26), 1-5. https://doi.org/10.1186/1746-4269-5-26

Bembridge, T.J., 1989, 'Aspects of small production in Ciskei', South African Journal of Animal Science 19(1), 1-3.

Bettencourt, E.M.V., Tilman, M., Narciso, V., da Silva Carvalho, M.L. \& de Sousa Henriques, P.M., 2015, 'The livestock roles in the wellbeing of rural communitie of Timor-Leste Piracicaba-SP', 53(1), SO63-SO80. http://doi.org/10.1590/123456781806-94790053s01005.

Boadu, A.A. \& Asase, A., 2017, 'Documentation of Herbal Medicines used for the treatment and management of human diseases by some communities in Souther Ghana,' Evidence-Based Complementary and Alternative Medicine, 1-12. https:// doi.org/10.1155/2017/3043061

Bradacs, G., Heilmann, J. \& Weckerle, C.S., 2011, 'Medicinal plant use in Vanuatu: A comparative ethnobotanical study of three islands', Journal of Ethnopharmacology 137(1), 434-448. https://doi.org/10.1016/j.jep.2011.05.050

Breyer-Brandwijk, M.G. \& Watt, J.M., 1962, The medicinal and poisonous plants of southern and eastern Africa, E and S Livingstone Ltd, Edinburgh.

Busia, K., 2016, Fundamentals of herbal medicine. Lighting source UK Ltd., Milton Keynes, UK, Volume 1 \& 2.

Chimonyo, M., Kusina, N.T., Hamudikuwanda, H. \& Nyoni, O., 1999, 'A survey on land use and usage of cattle for draught in a semi-arid environment,' Journal of Applied Science in Southern Africa, 5(2), 111-123.

Department of Forestry and Fisheries (DAFF), 2019, National livestock statistics, Statistics and Economic Publications and Reports, viewed n.d., from https://www. dalrrd.gov.za/Portals/0/Statistics\%20and\%20Economic\%20Analysis/ Statistical\%2OInformation/NEWSLETTER\%20LIVESTOCK\%20NOV\%2019.pdf

Deutschländer, M.S., 2010, Isolation and identification of a novel antidiabetic compound from Euclea undulata Thunb, University of Pretoria, Pretoria.

Deutschländer, M.S., Lall, N. \& van de Venter, M., 2009b, 'Plant species used in the treatment of diabetes by South African traditional healers: An inventory', Pharmacology and Biology 47(4), 348-365. https://doi.org/10.1080/13880200 902752959

Deutschländer, M.S., Lall, N., van de Venter, M. \& Dewanjee, S., 2012, 'The hypoglycemic activity of Euclea undulata Thunb. var. myrtina (Ebenaceae) root bark evaluated in a streptozotocin-nicotinamide induced type 2 diabetes rat model', South African Journal Botany 80(1), 9-12. https://doi.org/10.1016/j. sajb.2012.02.006

Deutschländer, M.S., van de Venter, M., Roux, S., Louw, J. \& Lall, N., 2009a 'Hypoglycaemic activity of four plant extracts traditionally used in South Africa for diabetes', Journal of Ethnopharmacology 124(3), 619-624. https://doi.org/ 10.1016/j.jep.2009.04.052

Dreyer, K., Fourie, L.J. \& Kok, D.J., 1999, 'Assessment of cattle owners' perceptions and expectations, and identification of constraints on production in a peri-urban resource-poor environment', Onderstepoort Journal of Veterinary Research 66(2), 95-102.

Dzoyem, J.P. \& Eloff, J.N., 2015, 'Anti-inflammatory, anticholinesterase and antioxidan activity of leaf extracts of twelve plants used traditionally to alleviate pain and inflammation in South Africa', Journal of Ethnopharmacology 160(1), 194-201. https://doi.org/10.1016/j.jep.2014.11.034

Endashaw, B., 2007, 'Study on actual situation of medicinal plants in Ethiopia' prepared for Japan Association for International Collaboration of Agriculture and Forestry, viewed 2 February 2020, from https://www.endashaw.com.

Galav, P., Jain, A., Katewa, S.S. \& Nag, A., 2010, 'Animal healthcare practices by livestock owners at Pushkar animal fair, Rajasthan', Indian Journal of Traditional Knowledge 9(4), 660-663.

Gebrezgabiher, G., Kalayou, S. \& Sahle, S., 2013, 'An ethno-veterinary survey of medicinal plants in Woredas of Tigray region, Northern Ethiopia', International Journal of Biodiversity and Conservation 5(2), 89-97. https://doi.org/10.5897/ IJBC12.131
George, J.E., Pound, J.M. \& Davey, R.B., 2004, 'Chemical control of ticks on cattle and the resistance of these parasites to arcaricides', Journal of Parasitology 129(Suppl), 353-366. https://doi.org/10.1017/s0031182003004682

Ghorbani, A., 2005, 'Studies on pharmaceutical ethnobotany in the region of Turkem Sahra, North of Iran (Part 1: General results)', Journal of Ethnopharmacology 102(1), 58-68

Giday, M., Asfaw, Z. \& Woldu, Z., 2009, 'Medicinal plants of the Meinit ethnic group of Ethiopia: An ethnobotanical study', Journal of Ethnopharmacology 124(2), 513-521. https://doi.org/10.1016/j.jep.2009.05.009

Graf, J.F., Gogolewski, R., Leach-Bing, N., Sabatini, G.A., Molento, M.B. \& Bordin, E.L., 2004, 'Tick control: An industry point of view', Jornal of Parasitology 129(1), S427-S442. https://doi.org/10.1017/s0031182004006079

Hadi, P.U., Ilham, N., Thahar, A., Winarso, B., Vincent, D. \& Quirke, D., 2002, Improving Indonesia's beef industry, Australian Centre for International Agricultural Research (ACIAR) Monograph No. 95.

Hunde, D., Asfaw, Z. \& Kelbessa, E., 2006, 'Use of traditional medicinal plants by people of "Boosat" sub district, Central Eastern Ethiopia', Ethiopian Journal of Health Science 16(1), 141-155.

Hutchings, A., Jager, A.K. \& Van Staden, J., 1996b, 'Plants used for stress-related ailments in traditional Zulu, Xhosa and Sotho medicine', Journal of Ethnopharmacology 52(1), 95-100

Hutchings, A.S.A., Lewis, G. \& Balfour, A., 1996a, Zulu medicinal plants, An inventory, University of Natal Press, Pietermaritzburg, pp. 37-235.

Kakudidi, E.K.Z., Bukenya-Ziraba, R. \& Kasenene, J.M., 2000, 'The medicinal plants in and around Kibale National Park in Western Uganda', Norwegian Journal of Botany (Lidia) 5(4), 109-124.

Kamatenesi, M.M., Acipa, A. \& Oryem-Origa, H., 2011, 'Medicinal plants of Otwal and Ngai Subcountries in Oyam District, Northern Uganda', Journal of Ethnobiology and Ethnomedicine 7(1), 7. https://doi.org/10.1186/1746-4269-7-7

Kamatenesi-Mugisha, M. \& Oryem-Origa. H., 2005, 'Traditional herbal remedies used in the management of sexual impotence and erectile dysfunction in western Uganda', African Health Sciences 5(1), 40-49.

Kioko, J., Baker, J., Shannon, A. \& Kiffner, C., 2015, 'Ethnoecological knowledge of ticks and treatment of tick-borne diseases among Maasai people in Northern Tanzania', Veterinary World 8(6), 755-762. https://doi.org/10.14202/ Northern Tanzania', Veterin
vetworld.2015.755-762

Leto, C., Tuttolomondo, T., La Bella, S. \& Licata, M., 2013, 'Ethnobotanical study in the Madonie Regional Park (Central Sicily, Italy) Medicinal use of wild shrub and herbaceous plant species', Journal of Ethnopharmacology 146(1), 90-112. https:// doi.org/10.1016/j.jep.2012.11.042

Lew-Tabor, A.E. \& Rodriguez Valle, M., 2016, 'A review of reverse vaccinology approaches for the development of vaccines against ticks and tick borne diseases,' Ticks and Tickborne. Diseases 7(4), 573-585. https://doi.org/10.1016/j.ttbdis.2015.12.012

Long, C., 2017, Swaziland's flora: siSwati names and uses, viewed 10 August, 2017, from http://www.sntc.org.sz/index.asp.

Lulekal, E., Zemede, A., Ensermu, K. \& Patrick, V.D., 2008, 'Ethnoveterinary plants of Ankober District, North Shewa Zone, Amhara Region, Ethiopia', Journa Ethnobiology and Ethnomedicine 10(1), 21. https://doi.org/10.1186/17464269-10-21

Luseba, D. \& Tshisikhawe, M.P., 2013, 'Medicinal plants used in the treatment of livestock diseases in Vhembe region, Limpopo Province, South Africa', Journal of Medicinal Plants Research 7(10), 593-601. https://doi.org/10.5897/ JMPR012.1213

Maroyi, A., 2017, 'Euclea undulata Thunb.: Review of its botany, ethnomedicinal uses, phytochemistry and biological activities', Asian Pacific Journal of Tropical Medicine phytochemistry and biological activities', Asian Pacific Journal of Tropical
10(11), 1030-1036. https://doi.org/10.10.1016/j.apjmtm.2017.10.005

Martins, J.R., Corrêa, B.L., Ceresér, V.H., Arteche, C.C.P., 1995, 'A Situation Report on Resistance to Acaricides by the Cattle Tick Boophilus microplus in the State of Rio Resistance to Acaricides by the Cattle Tick Boophilus microplus in the State of Rio y Control en Garrapatas y Moscas de Importancia Veterinaria III. Seminario y Control en Garrapatas y Moscas de Importancia Veterinaria
Internacional de Parasitologia Animal, Acapulco, Mexico, pp. 1-8.

McGaw, L.J. \& Eloff, J.N., 2008, 'Ethnoveterinary use of Southern African plants and scientific evaluation of their medicinal properties', Journal of Ethnopharmacology 119(3), 559-574. https://doi.org/10.1016/j.jep.2008.06.013

Menendez-Baceta, G., Aceituno-Mata, L., Molina, M., Reyes-Garcia, V., Tardio, J. \& Pardo-de-Santayana, M., 2013, 'Medicinal plants traditionally used in the northwest of the Basque Country (Biscay and Alava), Iberian Peninsula', Journal of Ethnopharmacology 152(1), 113-134. https://doi.org/10.1016/j. jep.2013.12.038

Mesfin, F., 2007, 'An ethnobotanical study of medicinal plants in Wonago Woreda, SNNPR, Ethiopia', MSc thesis, Addis Ababa University, Addis Ababa.

Mesfin, F., Demissew, S. \& Tekelaymanot, T., 2009, 'An ethnobotanical study of medicinal plants in Wonago Woreda, SNNPR, Ethiopia', Journal of Ethnobiology and Ethnomedicine 5(1), 28. https://doi.org/10.1186/1746-4269-5-28

Motlhanka, D.M.T. \& Nthoiwa, G.P., 2013, 'Ethnobotanical survey of medicinal plants of Tswapong North, in Eastern Botswana: A case of plants from Mosweu and Seolwane villages', European Journal of Medicinal Plants 3(1), 10-24. https://doi. org/10.9734/EJMP/2013/1871

Moyo, S. \& Swanepoel. F.J.C., 2010, 'Multifuctionality of livestock in developing communities', in F. Swanepoel, A. Stroebel, S. Moyo, (eds.), The role of livestock in developing communities: Enhancing Multifuctionality: The technical Centre for Agricultural and Rural Cooperation (CTA), pp. 1-12.

Mthi, S., Rust, J.M. \& Morgenthal, T.L., 2016, 'Partial nutritional evaluation of some browser plant species utilized by communal livestock in the Eastern Cape Province, South Africa,' Applied Animal Health and Rural Development, 9, 25-30. 
Mwale, M., Bhebhe, E., Chimonyo, M. \& Halimani, T.E., 2005, 'Use of herbal plants in poultry health management in the Mushagashe small-scale commercial farming area in Zimbabwe', The International Journal of Applied Research in Veterinary Medicine 3(2) 163-170.

Nana, P., 2010, 'Potential of integrating Calpurnia aurea with Entomopathogenic Fungus Metarhizium anisopliae for the control of Rhipicephalus appendiculatus and Rhipicephalus pulchellus', PhD dissertation in Zoology in the Jomo Kenyatta University of Agriculture and Technology.

Ntondini, Z., Van Dalen, E.M.S.P. \& Horak, I.G., 2008, 'The extent of acaricide resistance in 1-, 2- and 3-host ticks on communally grazed cattle in the eastern region of the Eastern Cape Province', Journal of the South African Veterinary Association, 79, 130-135.

Nyahangare, E.T., Mvumi, B.M. \& Mutibvu, T., 2015, 'Ethnoveterinary plants and practices used for ecto-parasites control in semi-arid smallholder farming areas of Zimbabwe', Journal of Ethnobiology and Ethnomedicine 11(1), 30. http://doi. org/10.1186/s13002-015-0006-6.

Ocaido, M., Muwazi, R.T. \& Asibo, O., 2008, 'Economic impact of tick borne-diseases on cattle production systems around Lake Mburo national park in South West Uganda', Tropical Animal and Production 41(5), 731-739. https://doi.org/10.1007/ s11250-008-9245-z

Palmer, E. \& Pitman, P., 1972, Trees for southern Africa covering all known indigenous species in Republic of South Africa, South West Africa, Botswana, Lesotho and Swaziland, A.A. Balkema, Cape Town, p. 792.

Rajput, Z.I., Hu, S.H., Chen, W.J., Arijo, A.G., Xiao, C.W., 2006, 'Importance of ticks and their chemical and immunological control in livestock', Journal of Zhejiang University-Science 7(11), 912-921.

Reta, R., 2013, 'Assessment of indigenous knowledge of medicinal plant practice and mode of service delivery in Hawassa city. Southern Ethiopia', Journal of Medicina Plants Research 7(9), 517-535. https://doi.org/10.5897/JMPR012.1126

Scialabba, N., 2000, 'Factors influencing organic agriculture policies with a focus on developing countries', in IFOAM 2000 Scientific conference, Basel, Switzerland viewed n.d., from http://www.fao.org/docs/eims/upload/230159/BaselSum-final. pdf.
Schmidt, E., Lotter, M. \& McCleland, W., 2002, Trees and shrubs of Mpumalanga and Kruger National Park, Jacana, Johannesburg, p. 702.

SPSS. 2011, Statistical Package for Social Sciences, Version 20, USA.

Soyelu, O.T. \& Masika, P.J., 2009, 'Traditional remedies used for the treatment of cattle wounds and myiasis in Amatola Basin Eastern Cape Province, South Africa', Onderstepoort Journal of Veterinary Research 76(4), 393-397. https://doi.org/ 10.4102/ojvr.v76i4.23

Sreekeesoon, D.P. \& \& Mahommodally, M.F., 2014, 'Ethnopharmacological analysis of medicinal plants and animals used in the treatment and management of pain in Mauritius', Journal of Ethnopharmacology 157(1), 181-200. https://doi. org/10.1016/j.jep.2014.09.030

Tamiru, F., Terfa, W., Kebede, E., Dabessa, G., Kumar, R.R. \& Sorsa, M., 2013, 'Ethnoknowledge of plants used in Veterinary Practices in Dabo Hana District, West Ethiopia', Journal of Medicinal Plant Research 7(40), 2960-2971. https://doi. org/10.5897/JMPR2013.5225

Tongco, D.C., 2007, 'Purposive sampling as a tool for information selection', Ethnobotany Research and Applications 5(1), 147-158. https://doi.org/10.17348/ era.5.0.147-158

Tyasi, T.L. \& Gxasheka, M., 2015, 'Use of remedies by illiterate small-scale farmers for treatment of livestock diseases in Bozwana Village, Lady Frere at Eastern Cape Province of South Africa', Journal of Biology, Agriculture and Healthcare 5(18), 82-86.

Yibrah, T., 2015, 'Medicinal plants in the ethno veterinary practices of Bensa Woreda, Southern Ethiopia', Open Access Library Journal 2(1), 1-12. https://doi. org/10.4236/oalib.1101258

Yineger, H. \& Yewhalaw, D., 2007, 'Traditional medicinal plant knowledge and use by local healers in Sekoru District, Jimma Zone, Southwestern Ethiopia', Journa of Ethnobiology and Ethnomedicine 3(24), 1-7. https://doi.org/10.1186/17464269-3-24

Yirga, G., 2012, 'Ethnobotanical study of medicinal plants in and around Ethiopia', Current Research in Journal of Biological Science 2(5), 338-344. 